\title{
Study of Congenital Anomalies Associated with a Consanguineous Married Couple
}

\author{
Rajesh N. Dehankar ${ }^{*}$, Ujjwala V. Bhakare ${ }^{2}$, Vishwajit M. Paikrao³, D.D. Ksheersagar \\ ${ }^{1 *}$ Associate Professor, ${ }^{3}$ Technician, 4 Professor \& HOD, Department of Anatomy, \\ ${ }^{2}$ Assistant Professor, Department Of Microbiology, \\ NKP Salve Institute of Medical Sciences and Research Centre, Nagpur, India.
}

\section{ABSTRACT}

Background: Consanguineous marriages are profoundly entrenched in Indian society. In most communities consanguineous marriages are traditional and respected. These intra familial unions collectively accounts for $20-30 \%$ in India, while globally it is around $20-50 \%$ of all marriages. There is high risk of congenital anomalies in children of consanguineous married couple.

Aim and Objective: This investigation was aimed to study the manifestation of the congenital anomalies associated with a consanguineous married couple.

Methods: The congenital anomalies such as Congenital Heart Disease (CHD), ambiguous genitalia, congenital cataract and recurrent spontaneous abortions are usually found in case of consanguineous married couple. The general parameters like age, sex and medical history was taken. The pedigree chart was prepared by using collected data. The child was examined for confirmation of the ambiguous genitalia. The ophthalmic examination of the child was carried out to classify the types of cataract. 2D ECHO was carried out to detect CHD. The standard Karyotyping method was used to confirm the karyotype.

Results: The congenital anomalies were confirmed in the children of consanguineous married couple. The pedigree analysis chart shows no family history of the $\mathrm{CHD}$, ambiguous genitalia or other developmental anomalies, but it was significant to note that parents are first-degree $\left(1^{\circ}\right)$ blood relatives. The child examination revealed that the child had ambiguous genitalia. The ophthalmic examination clarifies

\section{INTRODUCTION}

Consanguineous marriages are profoundly entrenched in Indian society. In minority and tribal communities consanguineous marriages are more common. Consanguineous marriage is defined as a union between two individuals who are related as second blood relatives or closer than that, with inbreeding coefficient $(F)$ equal to or higher than $0.0156,{ }^{1}$ where $(F)$ is a measure of the proportion of loci at which the offspring of a consanguineous union is expected to inherit identical gene copies from parents. The prevalence of consanguineous marriages in India is $20-30 \%$ and worldwide it is around $20-50+\%$ of all

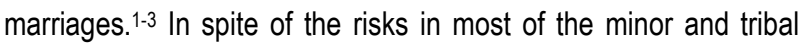

presence of bilateral Cerulean dot type of cataract. $2 \mathrm{D} \mathrm{ECHO}$ reveals the presence of $\mathrm{CHD}$. The Cytogenetic investigation confirmed the 46,XY karyotype in child.

Conclusion: From the result, it was concluded that the congenital anomalies like CHD, ambiguous genitalia, congenital cataract and recurrent spontaneous abortions in parents are associated with the consanguineous marriage. The parents were made aware about the risk of having abnormal child from next pregnancy. Counseling of the parents is needed to guide them about the necessary medical care of the child to increase survival rate.

Keywords: Congenital anomalies, Consanguineous marriage, $\mathrm{CHD}$, Ambiguous genitalia, Congenital cataract.

\section{${ }^{*}$ Correspondence to:}

\section{Dr. Rajesh N. Dehankar}

Associate Professor, Department of Anatomy,

NKP Salve Institute of Medical Sciences and Research Centre, Digdoh Hill Hingna Road

Nagpur, Maharashtra, INDIA

Article History:

Received: 08-08-2016, Revised: 02-09-2016, Accepted: 10-09-2016

\begin{tabular}{|l|c|}
\hline \multicolumn{2}{|c|}{ Access this article online } \\
\hline $\begin{array}{l}\text { Website: } \\
\text { www.ijmrp.com }\end{array}$ & Quick Response code \\
\hline DOI: & \\
10.21276/ijmrp.2016.2.5.045 & \\
\hline
\end{tabular}

communities in India consanguineous marriages are more traditional and respected.

The cause of a majority of human congenital anomalies are unknown, it may be genetic or due to environmental factors.

The various congenital anomalies like cleft lip, cleft palate, anencephaly, spina bifida, congenital heart diseases, pyloric stenosis, hypospadias, inguinal hernia, talipes equinovarus, and congenital dislocation of the hip are found in children of consanguineous married couple. In developing country like India the rate of pre marriage counseling is very low; they consult the doctors only if congenital anomalies appear in their children. 
According to Geneva international consanguinity report, the higher risk of congenital disorders is present in children of consanguineous parents with a reported average increased risk of $1.7-2.8 \%$ for the offspring of first blood relative couples over the baseline of $2-3 \%$ risk in the general population. ${ }^{4}$ From the report, it is clear that the child of consanguineous married couple have higher risk of congenital anomalies. Some of them have anomalies related to craniofacial, genitourinary, equivocal genitalia, musculoskeletal, respiratory, gastrointestinal, congenital cataract, central nervous systems, spleen and often associated with recurrent spontaneous abortions. ${ }^{5}$

In this study we focused on the congenital anomalies such as $\mathrm{CHD}$, ambiguous genitalia congenital cataract and recurrent spontaneous abortion associated with consanguineous married couple.

\section{METHODOLOGY}

\section{Data Collection}

The data of general parameters like age and sex was collected. The age at the time of diagnosis of cataract and heart defects were also recorded. Whether the patients have unilateral or bilateral cataract was noted. We also recorded the detailed history of occurrence of spontaneous abortion and medical history of parents and child. The presence of any consanguinity was investigated in the parents.

\section{Pedigree Analysis}

The pedigree chart was prepared using collected data. The presence of consanguinity was graded for the degree of relatives.

\section{Medical Investigations}

The structure of urogenital triangle of child was anatomically examined for confirmation of ambiguous genitalia. The ophthalmic examination was carried out to classify the types of cataract. 2D Echocardiographic (2D ECHO) was done to ensure presence of any heart disease as these cases often related to $\mathrm{CHD}$.

\section{Cytogenetic Investigation}

Cytogenetic investigation was carried out on case under study. The case show clinical features similar to ambiguous genitalia. PHA-stimulated peripheral blood leucocytes were cultured for 72 hrs in RPMI-1640 medium supplemented with $20 \%$ qualified; heat inactivated fetal bovine serum, $100 \mathrm{U} / \mathrm{ml}$ penicillin and streptomycin, without mitogene at $37^{\circ} \mathrm{C}$.

The culture was exposed to colchicine $(10 \mu \mathrm{g} / \mathrm{ml})$ for $30 \mathrm{~min}$ followed by hypotonic treatment $(0.075 \mathrm{M} \mathrm{KCl})$ for $20 \mathrm{~min}$ at $37^{\circ} \mathrm{C}$. Then fixed in Methanol: Glacial Acetic Acid (3:1) and dropped on wet ice cold grease free slides. The chromosomes were G-banded with trypsin-giemsa banding. Olympus BX51 Research microscope was used to screen, capture and karyotype the metaphase chromosomes. The results interpreted according to International Standard Chromosome Nomenclature (ISCN).

\section{RESULTS}

At the time of conception, the age of the mother and the father were 24 and 34 years, respectively. The age of child was 45 days, at the birth, child was considered as female. The birth weight of the proband was $2400 \mathrm{~g}$. The pedigree analysis showed no family history of the CHD, ambiguous genitalia or other developmental disorders, but it was significant to note that parents are firstdegree $\left(I^{\circ}\right)$ cousin and have history of spontaneous abortion (Figure 1).

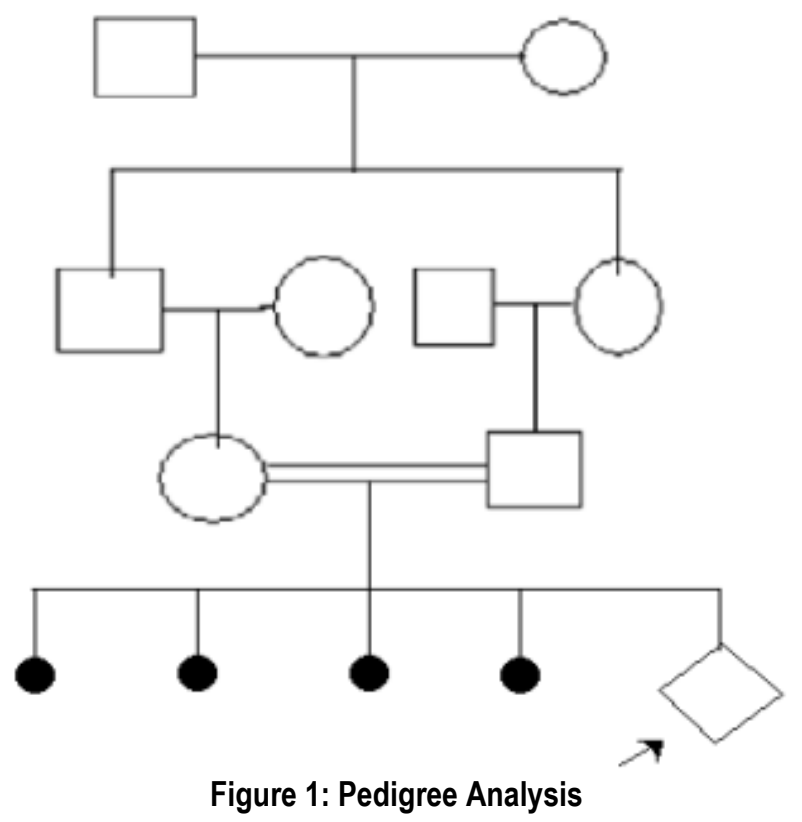

After anatomical examination, it is clear that the child has a micropenis and bilateral anorchia and labia major likes structure present anterior to micropenis. Urination carries out by micropenis like structure. The ophthalmic examination clarifies presence of bilateral Cerulean dot type of cataract. 2D Echo supported the presence of in developmental heart disorders. 2D Echo examinations revealed a ventricular septal defect (VSD) along with atrial septal defect (ASD) as CHD.

Table 1: Congenital anomalies observed in consanguineous married couples

\begin{tabular}{|c|c|c|}
\hline $\begin{array}{l}\mathrm{Sr} \\
\text { No }\end{array}$ & $\begin{array}{l}\text { Congenital } \\
\text { anomalies }\end{array}$ & Abnormality \\
\hline 1 & $\begin{array}{l}\text { Ambiguous } \\
\text { genitalia }\end{array}$ & $\begin{array}{l}\text { Micropenis and bilateral anorchia } \\
\text { and labia major likes structure } \\
\text { present }\end{array}$ \\
\hline 2 & Heart disease & $\begin{array}{l}\text { ventricular septal defect (VSD) } \\
\text { along with atrial septal defect } \\
\text { (ASD) }\end{array}$ \\
\hline 3 & Cataract & $\begin{array}{l}\text { Congenital cerulean dot type of } \\
\text { cataract }\end{array}$ \\
\hline 4 & Facial Anomalies & Unilateral Cleft lip \\
\hline 5 & $\begin{array}{l}\text { Anomalies in } \\
\text { anterior } \\
\text { abdominal wall }\end{array}$ & $\begin{array}{l}\text { Umbilical hernia is occasionally } \\
\text { observed }\end{array}$ \\
\hline
\end{tabular}

A 45-day old child with ambiguous genitalia was referred for karyotyping by the Pediatric OPD, at the birth, child was considered as female. Ambiguous genitalia are a condition where there is an abnormal development of the genital organ, which creates a question about the child's gender. Clinical investigations revealed that the child had ambiguous genitalia, congenital cataract, $\mathrm{CHD}$.

The ultrasonography of the internal organs revealed that the proband had both the ovaries and uterus, indicating the presence of an internal female reproductive organ.

Echocardiographic examinations revealed a ventricular septal defect (VSD) along with atrial septal defect (ASD) as CHD. 


\section{DISCUSSION}

The recurrent spontaneous abortion and birth defect, which includes the varying forms of ambiguous genitalia, cardiac abnormalities are the most common in the consanguineous marriages. The occurs with an incidence of 1 per 100 live births. In most of the cases, CHD is an isolated malformation, but about $33 \%$ have associated anomalies. Ambiguous genitalia are one such rare anomaly that is associated with $\mathrm{CHD}$ among other genital abnormalities. The possible causes for this association could be pseudohermaphroditism, consanguineous marriages have become the most important genetic cause of mortality and morbidity in the perinatal period.

In the study of Shawky and Sadik ${ }^{6}$ females were more affected with congenital anomalies (2.86\%) than males $(2.77 \%)$. This difference was however, not statistically significant. Other workers have reported a male excess for congenital anomalies.

In a recent study of Agopianet et al. ${ }^{7}$, the risk for gastroschisis in offspring was increased among women who reported having hot showers lasting > 15 minutes compared to < 15 minutes. In addition, they observed modest increase in the risk for spina bifida, cleft lip with or without cleft palate, and limb reduction defects in offspring of women who showered $>15$ minutes compared to $<15$.

\section{CONCLUSION}

From the result, it is conclude that the congenital anomalies- CHD, ambiguous genitalia congenital cataract and recurrent spontaneous abortion in studied parents are associated with the consanguineous marriage. The parents were need to aware about the risk of having abnormal child from next pregnancy. The parents also need to guide about the necessary medical care of the patient, which may increase survival rate of child.

\section{REFERENCES}

1. Bittles AH, Black ML. Evolution in health and medicine Sackler colloquium: consanguinity, human evolution, and complex diseases. Proc Natl Acad Sci U S A. 2010;107(Suppl 1):17791786. doi: 10.1073/pnas.0906079106.
2. Hamamy $H$, Antonarakis SE, Cavalli-Sforza LL, Temtamy S, Romeo G, Kate LP, Bennett RL, Shaw A, Megarbane A, Van Duijn $C$. et al. Consanguineous marriages, pearls and perils: Geneva international consanguinity workshop report. Genet Med. 2011;13:841-847. doi: 10.1097/GIM.0b013e318217477f.

3. Tadmouri GO, Nair P, Obeid T, Al Ali MT, Al Khaja N, Hamamy HA. Consanguinity and reproductive health among Arabs. Reprod Health. 2009;6:17. doi: 10.1186/1742-4755-6-17.

4. Marieke E T, Anouk H, Leo P K, Martina C C and Lidewij $H$. Challenges in the care for consanguineous couples: an exploratory interview study among general practitioners and midwives BMC Fam Pract. 2012; 13: 105.

5. Modell B, Darr A. Science and society: genetic counselling and customary consanguineous marriage. Nat Rev Genet. 2002;3:225-229. doi: 10.1038/nrg754.

6. Shawky, R.M. and Sadik, D.I. Congenital malformations prevalent among Egyptian children and associated risk factors. The Egyptian Journal of Medical Human Genetics, 2011, 12: 69 78.

7. Agopian AJ, Waller DK, Lupo PJ, Canfield MA and Mitchell LE. A case - control study of maternal bathing habits and risk for birth defects in offspring. EnvironHealth.2013;12: 88.

Source of Support: Nil. Conflict of Interest: None Declared.

Copyright: (c) the author(s) and publisher. IJMRP is an official publication of Ibn Sina Academy of Medieval Medicine \& Sciences, registered in 2001 under Indian Trusts Act, 1882.

This is an open access article distributed under the terms of the Creative Commons Attribution Non-commercial License, which permits unrestricted non-commercial use, distribution, and reproduction in any medium, provided the original work is properly cited.

Cite this article as: Rajesh N. Dehankar, Ujjwala V. Bhakare, Vishwajit M. Paikrao, D.D. Ksheersagar. Study of Congenital Anomalies Associated with a Consanguineous Married Couple. Int J Med Res Prof. 2016; 2(5):209-11. 